\title{
PECUNIA NON OLET BUT DOES ROSE MONEY SMELL? ON ROSE OIL PRICES AND MORAL ECONOMY IN ISPARTA, TURKEY
}

\author{
Lale Yalçın-Heckmann
}

\begin{abstract}
This paper investigates rose and rose oil production in the province of Isparta, Turkey, with reference to the discourses on and procedures of price formation. Farmers have been engaging in rose cultivation for over a century and rose oil production is considered to be a traditional industry. The market actors for rose oil are global cosmetic and local processing firms and almost all rose oil from Isparta is exported. Prices and production have been steadily increasing since 2010. Although prices are seen as good, there are concerns about over-production and fierce competition between the rose oil firms to buy the harvest, hence pushing up rose prices and, leading to a crash in rose oil prices on the world market. Through careful observation of payment and price formation procedures, the paper raises issues concerning the moral economy of price formation. Findings are provisional and the research is on-going, but the discourse on just prices clearly suggests that value judgements are embedded in and implicitly critical of capitalist markets.
\end{abstract}

Keywords: Rosa Damascena, rose oil, Isparta, price formation, perfume industry, moral economy

\section{INTRODUCTION}

Since every commodity, on becoming money, disappears as a commodity, it is impossible to tell from the money itself, how it got into the hands of its possessor, or what article has been changed into it. 'Non olet', from whatever source it may come.

Marx (1986 [1887]). Capital, vol. 1, p. 112).

Pecunia non olet (money does not smell): this famous saying is attributed to the Roman emperor Vespasian (ruled AD 69-79) who is reported to have collected tax money from Rome's latrines. Yet the saying is equally famous through Karl Marx, who used it in volume one of Capital (1887) to illustrate how money attached to a commodity through exchange does not reveal its source, has no smell so to speak. In this paper, I use the image of 'non-smelling money' to look metaphorically backwards, at how money earned from smells (of roses, which are distilled into rose oil to become raw material for perfumes) loses its 'smell' when it becomes price and profit. Smell is being used as a metonym for the social and cultural context of rose oil production in Isparta, southwest Turkey. Even if rose attar and perfume is the main and most luxurious output from this production, the 
profits earned are hidden, reminiscent of the fleeting, volatile fragrance of the rose and rose attar. In order to follow this process of exchange and transformation, I examine the conditions and process of rose farming and the procedure of rose oil production in the region of Isparta. The analysis is based on 6 months fieldwork in Isparta, carried out during several visits of different lengths in the period 2015-2018.

The smell I address here is that of roses, specifically that of the fragrant oil-bearing rose, Rosa Damascena, which has a restricted blossoming season of about two months a year. The fragrance is described as quickly evaporating after harvesting (Baydar \& Kazaz, 2013, p. 73), hence the distillation process needs to start immediately after roses are picked and processed as full flower blossoms. Roses have to be picked only when fully blossomed, not before (when still budding) and not after, since if post-blossoming the rose flowers lose their fragrant oil. The urgency of capturing the fragrance, however, seems to evaporate once the rose oil is produced. The money to be earned from harvested roses and produced rose oil does not reach rose farmers (growers) and rose oil producers (processors) until months after the harvest time and in the interim they do not even know how much it will be. Harvesting is done within 6-7 weeks from about May till the end of June; yet the prices of the roses and rose oil are made public to all the immediate actors only in late September or early October.

In this chapter I examine the factors affecting price formation ethnographically, following Jane Guyer (2009). She is not the first to take an interest in the composition of prices, and price formation as a process has been central to many economic sociological and economic anthropological analyses. These analyses have critically assessed simplistic assumptions about price formation (e.g. that price is determined only through the law of supply and demand) by positing markets as social fields (Bourdieu, 2005), highlighting the institutional aspects of price formation (Veblen, 1994 [1904], cited in Tool, 2002; Beckert, 2011), and underlining classical arguments concerning the embeddedness of prices in institutions, power and social relations, from Aristotle and Karl Marx to Karl Polanyi and John Kenneth Galbraith (cf. Krul, 2016). My interest in the formation of prices in and around the rose oil industry is related to my efforts to explore the 'moral dimensions' of this process, if not the 'moral economy' per se (Hann, 2018; Palomera \& Vetta, 2016).

The sentiments and norms of traditional obligations as expressed by growers and processors in Isparta, drew predominantly on the language and practices of market economy, notably with reference to 'good prices'. The question is how 'good prices' are related to a 'market-based economy' and at the same time linked to moral ideas about 'just prices'. Even if market-based economies at the local scale entail moral judgements and values (such as protecting the local growers and the rose as a local and traditional agricultural product), and further mutual obligations develop in economic transactions (such as respecting the competitors' price) (cf. Carrier, 2018), at the global end of the production and trade chain price formation increasingly lacks transparency and raises anti-market sentiments. These are clearer indicators of the moral dimension in economy (Hann, 2018), since public discourses on unjust prices reflect moral outrage and anxiety about the globalized capitalist 'market' and its local effects. The 'market' here consists of three fields: labor 
market in agricultural production, the market for roses in which rose growers and rose oil processors participate, and finally the global market for rose oil in which local rose oil processors and international perfume, cosmetic and aroma industry firms participate. Price formation hence is influenced by relations between and conditions in all these fields and at different scales of markets.

Gudeman and Rivera (1990, p. 139-159), discuss “just prices” from the perspective of Colombian peasants and suggest that peasants have multi-vocal views on prices, as well as on institutions of (market) trade and traders. They argue that the specialization implicated in the circulation of products from the locality to the markets through farmers, traders, and intermediaries such as transporters lead to the kind of disadvantaged (and marginalized) terms in which the peasants think of themselves and their inability to control prices and profits. They contrast themselves with the traders as follows:

[p]ersonal need for a commodity never forces traders to enter the market. In contrast, say the rural people, they themselves lack withholding power and have to make transactions based on necessity, which lowers their bargaining power (Gudeman \& Rivera, 1990, p. 151).

In the production chains I examine in this paper, I discuss whether and how marginalization, disadvantageous terms of trade and comparative advantages may emerge. The main difference, however, between the Andean peasant economy examined by Gudeman and Rivera and mine has to do with the way Isparta's rose growers are embedded into the global capitalist market economy. Roses in Isparta are cultivated for their good price and extra profits and they are not the only source of income for farmers. Furthermore the ecological conditions in Isparta give rose growers a relatively strong position where they exercise considerable power through following the market principle of demand and supply; they increase or decrease cultivation according to the price of roses and can nevertheless survive without it.

I argue that rose and rose oil production and the way prices are formed should be studied as a processual chain of integrated systems of production (of roses), trade (of roses) and production of rose oil (Production-Trade-Production), in which uncertainty is partly mediated through sociality between rose growers, scale keepers (kantarcıs) in the villages, and regional processors. Within this web of sociality prices are expressed as payments and profits are veiled through being related to distant markets, where big players engage in transforming the raw product of the rose oil through laboratory tests, perfume creation, branding, marketing, and advertisement (cf. Moeran, 2009 for a similar analysis of the transformative processes in incense production and marketing in Japan). Knowledge of this industry is not complete and is differentially available to local processors, and hardly at all to growers. Those processors who have tacit knowledge of these markets have an advantage over the growers, but they still have to compete with other processor firms to be able to dispose of their product at good prices. Following Elyachar (2012), I suggest that rose processors have a differential 'sense of the market' which enables them to - more or less - muddle through opaque processes of price formation.

First, I outline the location, the population and economy of the field site. I then describe the rose oil industry and how the price of rose oil and of harvested roses is set, drawing on literature in economic anthropology. I close by focusing on the articulations of moral dimensions of the economy through sociality and mutuality in the process of rose and rose oil production. 


\section{ETHNOGRAPHIC BACKGROUND: THE PROVINCE AND THE CITY OF ISPARTA}

Isparta is situated to the north of Antalya, which is internationally known for its beaches along the Mediterranean. Being located just to the north of the Taurus mountains and within the Turkish 'Lake District', the province enjoys a Mediterranean climate, with relatively cool summers (compared to the coast) and mild winters (compared to central Anatolia); this is conducive to rose cultivation. Since the foundation of the Turkish Republic in 1923 Isparta is known primarily as an agricultural province, growing grain, vegetables and fruit. In recent decades apples, pears and cherries have developed into important export cash crops. ${ }^{1}$

Rose cultivation in Isparta started in the late Ottoman period (Altıntaş, 2009; Temurçin, 2004). There are diverging narratives as to who initiated rose cultivation within and around the city, but legend has it that Ismail Efendi was the honorable patron of rose cultivation and first entrepreneur of rose oil production. The neighborhood where he is said to have set up the first rose gardens and to have lived is named after him as 'rose grower neighborhood' (Gülcü mahallesi) - the city of Isparta has made the rose its cultural symbol and brand, even if within the city there are no more extensive rose gardens nor rose oil production. Today the villages around the city of Isparta are the main locations for rose production, though many remember with nostalgia the existence and smell of rose gardens within the city boundaries (Karakuş, 2009, pp. 170-174).

In order to understand the conditions of rose and rose oil production, one needs to look at the general economic and socio-demographic features of the province. Isparta's urban population ( $60 \%$ of the provincial total, see Dulupçu \& Gövdere, 2012, p. 152) is employed mainly in trade and the services sector, with urban incomes derived primarily from rent (renting property to university employees and students, and also to military personnel). Rural population decline continues in all districts of the region, together with migration to other big cities and other provinces.

The discourse on the rose oil economy and its relevance for society in the province evokes tradition in addition to conservative and religious values. This discourse identifies rose oil as a symbol of Muslim culture and cultural consumption (e.g. rose oil is often referred to as being a symbol of the Prophet's facial sweat), rose water is considered a natural and non-alcoholic (hence halal) product, desired by many devout Muslims. The director of Gülbirlik (the major cooperative in rose and rose oil production in the province discussed below) was cited in a newspaper interview as wanting to donate rose water to wash the holy places of Mecca. ${ }^{2}$ Even if these discourses have no direct impact on rose and rose oil production, they show how this special industry is evoked as having significance in local culture and tradition, hence as worth engaging with and sustaining.

\footnotetext{
${ }^{1}$ In 2014 according to official agricultural statistics, $28 \%$ of the area in Isparta was used for agriculture. Of this some $82.6 \%$ is used for growing grains, $2.8 \%$ for vegetables and $14.6 \%$ for fruit production. See http://isparta.tarim.gov.tr/Sayfalar/Detay.aspx?SayfaId=29. Accessed on 11.09.2015.

${ }^{2}$ Roses and rose gardens indeed have long been part of the Islamic and Eurasian cultures as Goody (1993, pp. 101-119) illustrates. Goody (1993, pp. 103-106) mentions also the everyday but also therapeutic use of rose water and rose oil in Muslim countries from the Middle Ages onwards (see also Altıntaş 2009). For the news item about the director of Gülbirlik, concerning donating rose water to Mecca, see http://www.ispartahaberleri.com/isparta-haberleri/isparta-kabeyiyikayacak-gul-suyuna-talip-h1110.html, published on 13 May 2013. Accessed on 18 July 2015.
} 


\section{ETHNOGRAPHY OF ROSE PRODUCTION AND ROSE OIL INDUSTRY}

The rose oil industry is considered one of the most important industries in contemporary Isparta. Some 18 firms produce and export rose oil, some also create other rose products like rose concrete and rose absolute, all of which are used in products in the cosmetic, aroma, perfume, and food and health industries worldwide (Baydar \& Kazaz, 2013, p. 26). ${ }^{3}$ For this, production, distillation and extraction machines and some laboratory equipment are necessary, but on the whole it is not considered to be a very complicated or sophisticated procedure. The specificity of the production has to do with the immediate link between the rose harvest and rose oil production. During the harvest season, roses have to be picked daily from sunrise - ideally - for about five to six hours; they should not be harvested after $11 \mathrm{a}$.m. because the sun warms up the roses and causes the fragrant oil to evaporate. After harvesting, roses should be delivered to the factories as quickly as possible to be poured into cauldrons and then to be filled with water and heated for distillation. After about three to four hours and several distillation procedures, the raw rose oil can be collected.

The ratio of rose to rose oil in the production process is equally crucial: depending on the quality of the rose one needs from 2.5 to 3.5 tons of roses to produce one liter of rose oil. The productivity of a rose garden, depending on climate, soil, altitude and other factors is typically 3.5 tons from five decares ( 0.5 hectare) of land, meaning that from the harvest of this size rose garden one can extract 1 litre of rose oil (Baydar \& Kazaz, 2013, p. 8).

In Isparta province in 2015 roughly 10.000 farms (farming households) were said to engage in rose cultivation. ${ }^{4}$ These households cultivate roses in addition to other agricultural products, and practice animal husbandry. Baydar and Kazaz (2013, p. 20) indicate that only 20\% of individual farm land is used for rose cultivation and that the average acreage under rose cultivation is four to five decares.

According to official statistics, 20,487 decares of land ( $0.88 \%$ of total cultivable land) was cultivated for oil bearing roses (and lavender) and some 8,382 tons of roses were cultivated in 2015. ${ }^{5}$ Most income (69\% of agrarian income) is attained from fruit production, and farmers use most of their land for this activity/crop. However, the work load and the complexities of fruit cultivation and trade are mentioned as disincentives: rose cultivation does not depend on intermediaries ( $\mathrm{aracl}$ in Turkish, between the market and the producer) and is less vulnerable to climatic fluctuations (than cherries for instance). Indeed, rose production involves a much more direct connection between harvesting and transfer to the factory than other agrarian products; they cannot be stored and need to be transported immediately to the factory. Whether and how scale keepers (kantarcıs) can be seen as significant mediators is an issue I deal with below.

\footnotetext{
${ }^{3}$ Rose concrete is a solid extract and rose absolute is liquid. Rose concrete is distilled with hexane as solvent, which is different than the water-distillation method for extracting rose oil. Around 350-400 kg of flowers are needed to produce 1 $\mathrm{kg}$ of rose concrete, compared to the several tons of roses being distilled to produce 1 litre rose oil. This makes rose concrete also less expensive than the rose oil. Rose absolute is attained from rose concrete through using alcohol. All of these products are used in cosmetic and aroma industries.

${ }^{4}$ This is a very rough estimate and even if it is often cited by authorities and the cooperative, is nevertheless challenged by some rose oil producers as being an exaggeration.

${ }^{5}$ These are figures taken from the governmental statistics. See http://isparta.tarim.gov.tr/Sayfalar/Detay.aspx?SayfaId=29. Accessed on 11.09.2015. They are however challenged by some rose oil producers as being an exaggeration.
} 
At harvest time one first needs laborers; for instance, a farming household with three working adult household members, needs another two extra laborers at peak season for harvesting about two decares. The extra laborers may be relatives, neighbors, friends and/or waged agricultural day laborers. As I explain further below, prices for labor is set for each season as payment per kilogram picked on the day, the amount is recorded daily and payment is made at the end of the harvesting season. After picking, the sacks of roses are brought to the weighing station in the same village and are weighed by kantarcıs, men or women who are assigned by the rose oil firms to manage the specific weighing stations in the village. In villages where roses are cultivated there are at least five or six and sometimes up to eight or 10 such kantarcls, buying for different factories, processors, the cooperative and private firms. Their tasks are to weigh and issue receipts for the amounts collected from each farming household each day. They also record the amount picked by each hired laborer, which forms the basis for the laborers to claim their pay from their employers, the owner of the rose gardens. After weighing and recording the amounts, the sacks are transported by company trucks to the factories. The kantarcis may be members of the Cooperative ${ }^{6}$ and/or farmers themselves who may have some larger rose gardens. They must enjoy the trust of both the villagers and the firms. They are the key mediators between the firms and the rose growers, particularly in extending advance payments, for example, to combat agrarian parasites in the rose gardens, but also at times offering advance payments to growers for their life-cycle ceremonial expenses. They also play a crucial role in recruiting rose producers to sell to particular rose buyers, and also in the strategic use of knowledge about rose production levels by households, as I elaborate below.

The factories are not significant places of work. They have few permanent employees and employ up to 10 to 15 workers seasonally, for no longer than two months. Many firms have just one or two specialists responsible for the production of rose oil, rose concrete and absolute; (other employees include white collar administrators and laboratory technicians, and at least one watchman). A few firms produce other natural herbal oils (like lavender and thyme) and some larger firms may have more permanent staff and continuous production throughout the year. Rose growers feel and say they enjoy close contact with their firms, especially since the kantarcls are trusted and known persons. They are close-by and act as credit-givers on behalf of the rose oil firms in the village, an issue I shall come back to when discussing price formation.

The main labor market issue was the shortage of laborers for harvesting. Small farmers use their own household labor and on peak days mobilize their networks of relatives and neighbors. However, rural settlements are losing population and the labor supply in the villages is diminishing. Young people living in cities are asked and paid by their distant relatives or non-kin rose farmers to work as harvesters; young recent rural-urban migrants are the most suitable candidates. In May 2016 I accompanied rose pickers in two different locations. My impression was that rose pickers (mostly middle-aged women) had to work fast, fighting against time, often without a break for nearly seven hours; their labor conditions were different than from those in orchards, where workers are paid daily wages and not piece rates. This also means that their wages are fixed even

\footnotetext{
${ }^{6}$ The former state owned cooperative Gülbirlik is a major actor in rose cultivation and rose oil production. It is a union of cooperatives for producing and buying roses, and producing and selling rose oil; it also has a firm for producing cosmetic items. More on the cooperative, see below.

This article is (c) Emerald Group Publishing and permission has been granted for this version to appear here (https://pure.mpg.de/). Emerald does not grant permission for this article to be further copied/distributed or hosted elsewhere without the express permission from Emerald Group Publishing Limited. DOI: 10.1108/S0190-128120190000039004
} 
when the price of produce is not known. In May 2016 rose pickers were paid $1.20 \mathrm{TL} / \mathrm{kg}$ (ca. 37 euro cents). ${ }^{7}$ A very able picker might harvest about $35-40 \mathrm{~kg}$ a day, depending on the condition of the field and the time of season. Despite the very low pay for rose picking, some women said they like this work, as they can combine it with other kinds of work (e.g. paid work or unpaid household work). One needs to start early, and it is done by midday. Employers, however, complained that women recruited for a harvest season did not turn up regularly, presumably because of the low pay. Hence the laborers could walk away if they are unsatisfied with the wage, and farmers had to struggle to keep laborers if they did not want to leave their gardens uncultivated, by offering them better wages (more than the set price for the season) and extra benefits (such as providing them with food after the harvest, covering their cost of travel and arranging their travel to the fields at their own expense).

Farmers of larger holdings and some of the big rose oil firms which have bought or rented large fields for rose cultivation find it difficult to recruit reliable laborers in adequate numbers. These firms with large land holdings reported having to invest extra in providing accommodation to seasonal laborers. Migrant seasonal laborers from neighboring provinces, from the Southeast of Turkey (mostly Kurds), the local Gypsy population of Isparta, and more recently Syrian refugees who seek employment in the agricultural sector were the main population groups recruited. Yet legal status (for Syrian refugees without work permits until 2017), accommodation problems (for migrant native and Syrian workers) and work ethic (of Gypsies) were constant concerns.

I carried out interviews with the managers and/or owners of 15 of the province's 18 exporting private firms, in some cases returning for further intensive talks. Some of the private firms are small family enterprises, run by the second or third generation. Some are also involved in other branches of the industry, but all sold their rose oil and other rose products abroad. A few were involved in the cosmetic industry themselves and were in the process of developing their own brand of perfumes, rose water, eau de cologne and similar goods.

Apart from the rose oil distillers and exporters, numerous small firms bought rose water and rose petals to produce foods (such as Turkish delight and rose jam), or bought rose water for producing cheap cosmetics, soaps, and eau de cologne. The firms producing food for the local markets were also the ones buying roses directly in the villages from the farmers, offering the highest prices and immediate payment (peşin fiyat, in Turkish), but they bought small amounts and needed mostly roses which were not sprayed with chemicals. These products were sold in almost all stores in Isparta and were favored presents from the city. The larger and more established export firms accused the smaller firms of ruining the city's reputation, since many produced fake or low-quality cosmetic products, which were however affordable for Turkish buyers. These local firms producing food and cosmetics for local consumers do not have the capital to invest in the modern factory technology of distillation, nor would they have the business connections to export rose oil if they were to distill it. Some of the newcomers to the field of rose oil distillation for export indeed found

\footnotetext{
${ }^{7}$ On May 27, 2016, 1 Turkish Lira (TL) was equivalent to 0.30 Euros. In 2018, rose pickers were paid between 1.50 to 2 Turkish Liras, yet the Turkish currency had lost nearly one fourth of its value. On May 15, 2018, rose picking migrant agricultural labourers were being paid 1.5 Turkish Liras per kilo and this was equivalent to 0.29 Euros. 
it difficult to break into the international market for rose oil and lacked connections and business skills. $^{8}$

Special mention must be made of the former state-owned cooperative Gülbirlik (meaning 'rose union'), which is considered by all to be a major actor in both rose growing and processing. It is in fact a union of six smaller rose producing agricultural cooperatives and of a cosmetic industrial firm (http://www.gulbirlik.com/, accessed on 5 August 2017). The cooperative’s history follows the industrialization of rose oil production in the region: the first modern rose oil factory in Isparta had been established with state funding in 1935 (Altıntaş, 2009, p. 163), and this was followed by French investments for a second factory in 1952. The Rose and Rose Oil Producers Cooperative Gülbirlik was established in 1954 and took over the latter factory in the same year (Baydar \& Kazaz, 2013, p. 19). For nearly half a century, it was supported by the state, like other agricultural production cooperatives, before being subjected to restructuring and privatization in 2000, following the waves of privatization of many formerly state-owned cooperatives and enterprises. Presently it owns four rose oil distillation factories and two rose concrete production units (http://www.gulbirlik.com/, accessed on 5 August 2017). It has about 8,000 registered members ${ }^{9}$ and employs about 40 people permanently as administrators, with various expertise and functions. Gülbirlik established the cosmetic firm with the brand name Rosense in 2005 and produces its own cosmetic products, which retail all over in Turkey and abroad (http://www.rosensemagaza.com/sayfa/hakkimizda, accessed on 5 August 2017).

Gülbirlik differs from other buyer processor firms in that it represents growers, given its history and structure, and it sees itself as a guarantor for the growers' share in rose production. Although it is no longer financially protected by the state as in the previous years, it is still seen as being the major force for the continuation of rose production in the province. The managers of Gülbirlik in fact were keen to emphasize that the farmers would not continue growing roses if the cooperative were not there. Hence, even if the Cooperative does not give the best price and does not buy the largest share of the rose harvest from the growers, it is a major actor in the rose oil industry and especially in the formation of rose and rose oil prices. The most significant role of Gülbirlik concerning the price of roses is that in earlier times they were the first to declare the sale price of roses (taban fiyatı in Turkish, which means base price) and the private firms adjusted their own prices to that, offering a small amount on top of Gülbirlik's price. This tradition has been kept since the privatization of Gülbirlik in 2000. What consequences these price setting mechanisms have is an issue which I address further below.

\section{CONTEMPORARY ISSUES IN ROSE OIL PRODUCTION}

Rose oil and other rose products are considered a traditional industry, which has given the province a name and brand (Sallan Gül, Yılmaz, Ergun, \& Alican, 2010). Yet many are worried that it might

\footnotetext{
${ }^{8}$ My several contacts with international cosmetic firms (mostly in organic cosmetics) support this impression; they are selective about their business partners and prefer long-term relations.

${ }^{9}$ See http://www.gulbirlik.com/, accessed on 5 August 2017. According to the Cooperative's managers, the number of active members 'regularly selling rose to the Cooperative', however, is some 3000.
} 
share the fate of another traditional industry, that of hand-woven carpets, which were known as Isparta carpets until the 1970s and 1980s (see Erçetin, 2014, pp. 102-124). Since the introduction of machine-woven carpets, none have been produced in the province by traditional methods.

Despite these anxieties, rose oil production remains an attractive industry, primarily because of rising prices and earnings for all (growers as well as processors). In the history of rose production in the province, however, there have been several cases of boom and bust, for example, in 1986, in the 1990s, the early 2000s, and in 2010. ${ }^{10}$ My interlocutors at Gülbirlik explained this phenomenon by the attractiveness and ease of rose growing. When rose and rose oil prices increase, this causes overproduction and flooding of the market with rose oil, and rose processors have difficulty in selling their produce on the global market, where demand is stable. Hence rose oil prices commonly crash, leading to a crash in rose prices. Such boom-bust cycles lead rose growers to give up their fields and some rose oil processors have closed down. At boom times, when rose oil prices increase and cause high rose production, new small and middle size firms start up business; this seems to have been the case since 2010. After 2015 more established and older processor firms complained about the many newcomers to the market, fiercely competing with them to buy the roses, as I shall elaborate further below. Official sources claim that the province supplies at least $50-60 \%$ of world market demand for rose oil. ${ }^{11}$ Gülbirlik, representing the majority of growers in Isparta, have been warning against overproduction of roses and rose oil since 2012, ${ }^{12}$ demanding state control of production areas and state support in improving the quality of rose cultivation. ${ }^{13}$ The rose gardens need to be renewed every 20 to 30 years as the yields decrease, hence Gülbirlik and private processors - were seeking state support for the farmers who want to renew their gardens and be subsidized during those few years of planting new rose plants.

Boom and bust and how to prevent price falls are a major concern in the province. Several firm owners support the idea of developing and enlarging the area of rose cultivation, encouraging more organic cultivation (as a response to world market changes and demand) and improving quality control.

In general, some of the problems related to rose cultivation were of a more universal character and related to demographic problems in the rural sector in recent decades; these are issues which need to be dealt with separately. In Isparta, decline in rural population and increase in city population are common trends, as in many other parts of Turkey and the world. Hence agrarian land ownership and agricultural production are said to need reorganization. Privately owned processor firms tended to view small land ownership as an obstacle to improving the quality and productivity of gardens, whereas for Gülbirlik small land owners were their actual and potential members. Accordingly, its managers favored varying kinds of state support and incentives for the

\footnotetext{
${ }^{10}$ For fluctuations of rose cultivation areas and prices in Isparta between 1987 and 2010 see Yürekli Yüksel (2010, p. 3). Moeran (2010, p. 425) mentions similar fluctuations and struggles over rose prices in Bulgaria, the other major country for growing Rosa Damascena and producing rose oil.

${ }^{11}$ Altıntaş (2009, p. 169) claims that contemporary Turkey supplies $70 \%$ of the world demand, with Isparta the leading province. In an interview, she also suggested that rose oil has a very broad range of use in food industry because it is a basic natural essence for aromas, used even in the cigarette industry.

${ }^{12}$ See http://www.bomba32.com/haber/isparta/gulde-tehlike-canlari/3432.html, accessed on 14 January 2018. There have been earlier warnings by Gülbirlik during previous boom and crash cycles, see their journal (Gülbirlik 2007, pp. 6-7).

${ }^{13}$ Internal and unpublished report by Gülbirlik (2011, p. 2).
} 
farmers. Nevertheless, they also saw the continuous increase in the area of cultivation as a potential danger which could lead to a sharp fall in rose and rose oil prices.

\section{ROSE OIL INDUSTRY AND PRICE FORMATION}

As indicated in the introduction, each year the price of roses is determined not at the time of harvesting, but after the roses have been processed and the products have been sold on the world market. The price of roses in 2015 was 'declared' by Gülbirlik at the end of September (in the period 2016-2018, it was in October), hence causing three or more months of uncertainty after cultivating and processing the roses.

Rose production is easy, but productivity is dependent on climatic conditions. If winter has been late, cold with sudden spells of frost, or if spring rain is insufficient, the harvest may be low and there will be a shortage of roses for the processor firms. This was the case in 2015. In 2016, winter was exceptionally mild, hence the roses blossomed earlier than usual; the harvest started at the beginning of May. In 2018, the harvest had already started by mid-April, ending in late May. As in the harvesting seasons in 2016, 2017 and 2018, frequent rains during harvesting prolong the work and increase the length of harvest time.

Chronic shortages of labor may cause delays in picking the roses, causing the oil content to evaporate. When conditions of ecology and labor are fulfilled, the firms produce the oil and the rose concrete according to their capacities and available technologies. They process the harvested roses depending on their quality into either rose concrete or rose oil; for this they need to estimate which one would sell better that year. Firms in France, Switzerland, USA, UK, Japan and Germany are the most important buyers (Altıntaş, 2009, p. 173; Baydar \& Kazaz, 2013, p. 21) and more recently Middle Eastern buyers have joined the market for buying rose oil and rose concrete. The sale of rose oil and rose concrete to these cosmetic firms takes place during the late summer and early autumn months. The processors say that the buying companies wait for their price offers. The processors then make their offers on the basis of the prices from the previous year and their own estimates about the overall production level of rose oil and rose concrete in the region that year. But these production levels are estimates only and how much rose oil and concrete are actually produced by each company remains a company secret. Experienced processors of course know roughly how many tons of roses were cultivated that year (and the estimates of their own kantarcis are crucial here) and they also approximately know the production capacity of the rose oil firms in Isparta. Nevertheless, they wait and try to find out what price other companies are offering. Furthermore, the quality and amount of roses used in producing a liter of rose oil remains a company secret. Rose growers, for instance, do not have scientific measures or means for assessing the quality of their own roses other than the fact that processor firms continue their payment relationships. ${ }^{14}$ The logic is that if their roses are of good quality, the processors would be keen on

\footnotetext{
${ }^{14}$ Other than the rule of thumb about the altitude, soil quality of the location and good care of the gardens, rose farmers do not have any means to be sure about the quality of their roses. The final quality is assessed when rose oil firms offer their product on the world market; it is often the buying perfume and cosmetic firms who measure the quality from samples and then make their price offers.
}

This article is (c) Emerald Group Publishing and permission has been granted for this version to appear here (https://pure.mpg.de/). Emerald does not grant permission for this article to be further copied/distributed or hosted elsewhere without the express permission from Emerald Group Publishing Limited. DOI: 10.1108/S0190-128120190000039004 
maintaining trade relations with them and willing to make advance payments and offer 'good' prices at the end of the season. Rose growers' lack of knowledge about processing, marketing and the quality of rose oil was one of the aspects contributing to the opaqueness of price formation. As one rose grower observed, when asked why they do not establish a distillation unit close to the village and get more direct advice about tending their gardens which suffer at times from parasites, 'then we could learn how the whole production system works'. She implied that attaining more knowledge about production would raise growers' bargaining power.

In this web of relationships and transactions between the processors, the Cooperative, rose growers and kantarcis, and during this period of 'price formation', there are several guidelines or unwritten rules. (1) The private processors wait for the Agricultural Cooperative Gülbirlik to 'declare' its buying price for roses. (2) They try to understand what the components of that price are (e.g., cooperative membership fees, various kinds of taxes). ${ }^{15}$ (3) They offer a price which does not 'exceed too much' the price offered by the Cooperative. The common formulation goes something like this: Gülbirlik's (price) plus 50 Kuruș (equivalent to half of one Turkish lira).

I argue that there is a good deal of secrecy and 'mystery' about this price formation. In 2016, in the weeks after the harvest, the firm owners or managers expressed uncertainty, saying that they had a rough idea, but that it was not a fixed price yet. The reason why the private firms followed the price set by the Cooperative was - as some suggested - the 'security' the Cooperative was able to offer to rose growers. Both Cooperative and private firms argue that the rose growers would prefer to sell to the Cooperative because (as a former state coop), it 'naturally' defends their interests. Many private firms see themselves at a disadvantage because of this, but at the same time accept the Cooperative's mimicry of 'being like the state sector' as a historically formed attitude and a given. This is reminiscent of the part played by 'custom' in price formation, where it plays a stabilizing and representational role, as described by Guyer (2009, p. 212). Furthermore, in conversation, the processors as well as the growers were almost unanimous that the 'declaration of a minimum rose price' by the Cooperative was a necessary restraint on private firms' 'greed' and possible attempts to dominate or monopolize the market. The common rhetoric from private firms was not to 'cool off' or 'disappoint' (küstürmek) the rose growers, who historically and 'naturally' would support the Cooperative. Rose farmers had indeed given up cultivating roses and left their gardens uncultivated and changed to another produce on several occasions. As explained above, when prices crashed many farmers changed to planting fruit trees instead. One of the farming families, for instance, had planted a new rose garden in which the roses were placed between rows of newly planted cherry trees. In 2016, they said that they would not keep both since the plants would hinder one another for lack of space and sunlight. They wanted to wait to see how prices developed and give up on one of them accordingly, and indeed in 2018 when I revisited them, they had cut down some of their cherry trees and were already harvesting the roses.

The rose growers too, wait until the Cooperative declares that year's price of roses. The growers get paid for the quantity of roses they deliver each year, but this payment is usually less than the

\footnotetext{
${ }^{15}$ The Cooperative offers different prices to the member growers on the basis of duration of membership, I was told. Also the taxes and payments to the Chamber of Trade etc. are also accounted for, and the private firms adjust their own prices accordingly.

This article is (c) Emerald Group Publishing and permission has been granted for this version to appear here (https://pure.mpg.de/). Emerald does not grant permission for this article to be further copied/distributed or hosted elsewhere without the express permission from Emerald Group Publishing Limited. DOI: 10.1108/S0190-128120190000039004
} 
total amount of roses multiplied by the fixed price, because almost all growers have annual agreements to sell their roses to one or several rose oil firm(s) and receive advance payment before harvest time. ${ }^{16}$ After the harvest they receive the remaining payment for deliveries from that year and simultaneously a contract for the coming year. Therefore, the announcement of the 'price of roses' means that the price is for settling the accounts of advance payments and remaining payments: prices are in fact payments, a distinction highlighted by Jane Guyer. She reminds us of Polanyi's discussion of prices and payments, where he contrasted fees as payments to prices as exchange (Guyer 2009, p. 215, citing Polanyi 1977). ${ }^{17}$ I shall return to this point below.

The advance payments (called avans ödeme in Turkish) were introduced by the private firms to secure the growers' harvest and delivery of a certain quantity each year. ${ }^{18}$ The amount is necessarily an estimate since the harvest may fluctuate, and growers may deliver more or less than expected. In earlier years the Cooperative apparently criticized the advance payments made by private firms as a mechanism promoting an artificial increase in the price of rose, hence causing unjust prices; they express this as "unethical and unpreventable unfair competition" (in Turkish "etik olmayan ve önlenemeyen haksız rekabet") in their reports. ${ }^{19}$ But in 2015, when rose growers had already been increasingly selling to private firms which pay these advance payments, the Cooperative started paying advance payments as well. The Cooperative explains this payment, however, as the distribution of gains due to fluctuations in exchange rates and not as 'advance payments'; the private firms see it differently. The advance payments were more controversial a year later, when some complained that they were inflationary. The kantarcıs seemed to play a crucial role in guiding the offers of advance payments, and also in checking the reliability of the farmer (for delivering the harvest or being able to pay back any excess advance). Some private processors talked about a 'war' between rose buyers, alleging that some other buyers were like 'cannibals' (yamyam, in Turkish), trying to 'eat up' one another by offering ever higher prices to the growers. The image of rose buying firms engaging in unbounded and immoral competition with one another was confirmed by some cooperative managers, who would accuse the private sector of greed and 'having an eye on what is on the growers' table' (sofraya göz dikmek), suggesting that the food on the table, and hence livelihoods, would be in danger.

All payments to farmers in 2015 and 2016 were made without full legal endorsement. The farmers signed agreements with the firms and advance payments were recorded on paper. Yet the processor firms were not keen to take any legal action (and said this has never happened), if the promised quantity of roses was not delivered. The contracts (and debts) were simply extended to the following year. One kantarcı said that he would be liable for the amount of money which had been lent for distribution to the farmers, and the kantarcis would have to recoup the payment from each indebted farmer. In this way the processors could be seen as acting as 'informal' banks, giving credits (on behalf of processor firms) on the basis of trust and social relations, without interest. The

\footnotetext{
${ }^{16}$ They can and do often sell their roses to more than one buyer, especially if they have larger land holdings.

${ }^{17}$ Guyer (2009, p. 215): "Money as exchange is for 'the acquisition [...] of desired goods" (Polanyi 1977: 104), whereas money given in payment "is the discharge of an obligation by handing over quantified units" (Polanyi, p. 105). She suggests that the former reflects primarily market forces; the latter social relations.

${ }^{18}$ This may be as long ago as the1980s, when numerous new private firms entered the rose oil market.

${ }^{19}$ Unpublished report made available by Gülbirlik to the author.
} 
role of the kantarcıs is to secure a strategic distribution of debts, tying the growers to the processors and then collecting the harvest/debt from the growers. ${ }^{20}$

\footnotetext{
${ }^{20}$ The kantarcıs are commonly paid a percentage per kilo rose they collect from the farmers. Some of them (as in the case of the Güneykent cooperative, which has separated itself some years ago from Gülbirlik) do not pay this percentage and the task is carried out by a member of the cooperative, I was told. When kantarcıs take on this role of distributing advance payments to the farmers from the total lump sum provided by the processor firm, I assume (but cannot confirm) that they may be getting a special payment for their efficiency.
}

This article is (c) Emerald Group Publishing and permission has been granted for this version to appear here (https://pure.mpg.de/). Emerald does not grant permission for this article to be further copied/distributed or hosted elsewhere without the express permission from Emerald Group Publishing Limited. DOI: 10.1108/S0190-128120190000039004 
Table 1. Rose and Rose Oil Prices in Isparta (2010-2017).

\begin{tabular}{|c|c|c|c|}
\hline Year & Rose Price (TL/Kg) & Rose Price (Euro/Kg) & $\begin{array}{c}\text { Rose Oil Price } \\
\text { (Euro/Kg) }\end{array}$ \\
\hline 2010 & 1.85 & 0.95 & 5,250 \\
\hline 2011 & 2.20 & 0.92 & 5,500 \\
\hline 2012 & 3.00 & 1.28 & 6,250 \\
\hline 2013 & 3.50 & 1.40 & 7,250 \\
\hline 2014 & 4.20 & 1.45 & 7,000 \\
\hline 2015 & 5.80 & 1.93 & 9,000 \\
\hline 2016 & 7.65 & 2.26 & 11,000 \\
\hline 2017 & 8.70 & 2.04 & ca. 9,000 \\
\hline
\end{tabular}

Table 1 shows rose and rose oil prices in Isparta between 2010 and 2017. Comparing the price increase for roses one sees that in Euros the increase from 2010 to 2016 is more than double; but for rose growers the price of roses calculated in Turkish liras rises more than fourfold. For rose oil, the price increase in Euros within the same period of 2010 to 2016 is slightly more than $100 \%$. In 2017, rose oil prices were reported to have crashed; in late summer there were rumors that some firms were having difficulty selling their rose oil for even 9,000 Euros, hence 2,000 Euros less than the previous year. Gülbirlik decided not to crash the price of roses, however, and paid even somewhat more than the previous year in Turkish liras, although the international Euro price decreased. As rose farmers are paid in Turkish lira and the rose oil producers sell their rose oil abroad and are paid in foreign currency, keeping the rose price at a satisfactory level for rose growers was still possible, due to currency exchange rates. ${ }^{21}$ In 2016, all parties were declaring themselves satisfied and talked about 'good prices'. In 2017, some of the private sector rose processors were seriously worried about not being able to sell their produce, especially if they specialized in rose oil production alone. Gülbirlik gave press interviews highlighting the large sums of foreign currency earned through export in Isparta's rose industry, yet the figures cited reflect an emphasis on rose concrete production and sale in comparison to rose oil. ${ }^{22}$ Rose concrete is more often and broadly used in the cosmetic industry and is cheaper than rose oil; the latter is an essential ingredient for some of the traditional trademarks of exquisite and expensive perfumes.

\footnotetext{
${ }^{21}$ Currency exchange rates have been strongly fluctuating since October 2017 when rose prices were declared. On January 14, 2018, 8.70 TL was equivalent to 1.90 Euros, but on July 12, 2018, it had dropped to 1.55 Euros.

${ }^{22}$ See https://www.sondakika.com/haber/haber-turkiye-ekonomisine-40-milyon-avroluk-gul-duren-10120739/ published on October 11, 2017, and http://www.haberturk.com/yerel-haberler/haber/9652954-ispartadan-30-milyon-avroluk-gulihracati, published on October 7, 2016, both accessed on 12 January 2018. In 2017 1,500 kg rose oil and 15 tons rose concrete was produced, when the harvest is said to have been over 8,500 tons of roses. In 2016, it has been estimated that rose harvest was about slightly over 7,000 tons, and 1,300 kg rose oil and 15 tons rose concrete had been produced. These figures show that even if the harvest has increased significantly from 2016 to 2017, the rose oil and rose concrete production have not followed suit at the same rate.
} 
CONCLUDING DISCUSSION: THE MORAL DIMENSION AND JUST PRICES IN THE ROSE OIL ECONOMY

The idea of moral economy, as Hann (2010, 2018), Carrier (2018) and others have commented, has been conceptualized and developed primarily in relation to small towns and industrial manufacturing. Scott (1976) is commonly associated with applying the concept to the rural context, studying Southeast Asian peasants' concepts of justice and the subsistence ethic in relation to rural production (see also Luetchford, 2012). In my view, these discussions on the moral economy of the peasants in Scott's sense cannot be applied to Isparta's rose growers. Rose cultivation is considered as a bonus, as a commodity and source of an extra 'good' income. It is a side income providing extra money, and it is flexible because it is easy to start and give up.

Nevertheless, the formation of prices, that is, the annual increase in rose and rose oil prices, were seen with apprehension. The growers evaluated increases in rose prices positively, yet they were aware of the rate of increase in rose oil prices and did not want to miss out on the best offers from processor firms. In those villages where rose growing is intensive and almost all households engage in it, processor firms competed for the growers' roses and kantarcıs had to use various strategies and increase mechanisms of sociality to convince farmers to sell to their particular firm. In Güneykent, for instance, which is such a center of rose cultivation, there were ten kantars (scales) for buying roses between May and June 2016, kantarcıs lined up often next to one another on the rural settlement's main roads. As rose prices promised to be 'good' again in 2016 and even in 2017, farmers expressed their expectations that higher rose oil prices might bring them better rose prices. Farmers were aware of rose oil prices but did not pay much attention to them, since the actual crash in rose oil prices in 2017 was not mentioned in the news. In 2018, the rose growers were still expecting a rise in rose prices and on the whole were unaware or unwilling to believe in the crash of rose oil prices, and that processors have not been able to sell their rose oil. The rose price which was made public in October 2018 had gone indeed down to the price of 2016.

The buyers of roses, that is the processor firms, could be thought to have the obvious advantage in that they are informed about the demand for rose oil and possibilities of expansion on the world market. Nevertheless, they also express great concern that this demand might crash (as happened again in 2017), and that the international cosmetic industry and their traditional partner firms will (and do) not buy rose products at these constantly increasing price levels. Processor firms compete with one another to buy the best (e.g., roses from the slopes which are considered to contain a higher percentage of fragrant oil) and most roses, they also compete with one another to offer good prices to the cosmetic industry and to maximize their profits.

This is where transparency becomes opaque. The quality and the quantity of roses used in producing a litre of rose oil, as well as the amount of rose oil produced remain a company secret. Furthermore, the profits of the processors remain a vague issue and hence a source of mistrust for rose growers (cf. Luetchford, 2012). The small farmers in Costa Rica studied by Peter Luetchford say that cutting out the intermediaries from trade relations would be an important strategy for restoring justice in exchange (2012, p. 403). Gudeman and Rivera (1990) report similar concerns 
among the peasants in Colombia. In the case of Isparta, the kantarcis cannot be considered as intermediaries in the same sense as has been discussed for other agricultural produce like coffee (Luetchford, 2008), tea (Besky, 2014) or cut flowers (Ziegler, 2007). It is the price relationship between the cosmetic and perfume industries and the processor firm which is the source of lack of clarity and trust.

The payments made by processors on the one hand, give them a morally anchored if not superior position in the exchange relationship with the growers, since they offer advance payments for the harvest before the harvest season. These function through social relations and provide security, and are emphasized over and above being simply about prices and the market. Hence with this strategy the non-transparent profits are, if not legitimized, at least veiled. In this respect, the strategy of advance payments although resembling bank credits, differ from these in the following ways: they are offered to growers without interest, quite often are not legally endorsable contracts, and they are administered through intermediaries in the villages in personalized and informal ways. One processor said, for instance, that he knows the farmers so well that he can estimate when they would need cash, and that he also buys other produce (such as animal products) from them. This indicates the multi-layered character of his relations with farmers. The purpose of advanced payments is recognized by all; it is to bind the rose farmer to the processor. But this binding is partly veiled and embedded in sociality; it is a moral obligation to give the harvest to the rose oil firm from which one has taken advance payments (i.e. mutual moral obligations, as discussed by Carrier, 2018). Some claim that the processor firms in their effort to bind the farmers with this moral (and hardly legally backed) obligation ask farmers if they want money before the harvest and independent of the rose money payment dates. They offer money whenever the farmer is in need, in installments and without any complicated bureaucratic procedures (without providing collateral), but primarily on the basis of trust with the firm's kantarcl.

As discussed above, the kantarcıs take responsibility for making payments to the farmers and collecting them back from them. They themselves are financed by a large sum of money from the processor firm, which they recoup in harvested roses in May and June. If the farmer brings in less than the amount agreed upon at the time of receiving the advance payment, then the remaining amount of harvest/debt/money is transferred to the next year. The kantarcıs employed by the processor firms also make agreements about their pay by the same firms; sometimes this payment is left ambivalent, if the relationship is one of trust, lasting across generations (of firm owners and kantarcis) and they might formulate it as a 'satisfactory payment'. ${ }^{23}$ The idea, therefore, is to continue the payment and exchange relationship, providing the kantarcıs 'keep' the farmers, and as long as the farmers bring in the harvest, and the processor firms tolerate the delays and unfulfilled promises of the rose harvest. Along these lines of relations, where actors are entangled in the process of growing and processing roses and selling them so that payments in line with the prices, the components of the price are transformed and rendered ambivalent, without smell, non olet. In

\footnotetext{
${ }^{23}$ In general kantarcls are paid according to the amount of rose they buy for the firm, per $\mathrm{kg} 10$ kuruş, for instance. The kantarcıs working for the Cooperative were paid in this way. But there were cases where the processor firm owners would also be involved in long-term relationships with the kantarcls and hence be promising but not precise about the payments at the beginning of the season.
}

This article is () Emerald Group Publishing and permission has been granted for this version to appear here (https://pure.mpg.de/). Emerald does not grant permission for this article to be further copied/distributed or hosted elsewhere without the express permission from Emerald Group Publishing Limited. DOI: 10.1108/S0190-128120190000039004 
this way a financial relationship is transformed or euphemized as a social relationship. This allows processors to control growers to a certain extent and divert attention away from markets and prices.

To conclude, I return to Jane Guyer's warning in her 2009 contribution to the book Market and Society, that taking price as the simple mediator between supply and demand would be a fallacy, and that there are good reasons for 'making explicit' ethnographically the components of price for understanding the moral dimension of economies. That price veils value has been a longestablished argument since the time of Marx.

Elyachar has investigated the nature and embeddedness of the markets in the Middle East and reminds us of the region's long and earlier histories of globalization, of markets and states, and early monetization (2005, p. 23). She argues that, contrary to the opposition between gift and market economies as suggested by Mauss, Malinowski and Adam Smith, gift economies have been as integral parts of these markets as commodities and monies (Elyachar, 2005, pp. 21-23). The entanglements between the payments and prices, and the sociality involved in making the price of rose and rose oil may well be pre-market and pre-capitalist as well as capitalist. This needs to be pursued by further exploration of the gift, payment and prices in Turkey on a broader scale.

In her work on the public sector and markets in Egypt, Elyachar describes a state employee at a bank who skillfully manages bank loans and access to markets for customers with his "sense (hiss) of the market” (2012, p. 78). For Elyachar, this is skillful employment of tacit knowledge. Tacit knowledge, as explored extensively by Michael Polanyi, indicates "unsystematized, unverbalized forms of knowledge that were integrated into the body itself, rather than being formed in the brain through the study of books” (Elyachar, 2012, p. 83). Many of the processor firm managers and owners I have talked to suggested to me also this 'feeling for the market', that they had to muddle through the possible price changes and "guesstimate" the rose harvest. Their 'feeling for the market' also functioned to veil price formation. ${ }^{24}$

To understand the tacit knowledge about and veiled components of price making in the rose oil industry and to clarify the tensions inherent in this process of price making and production planning strategy, I have examined the social relations around payments and prices. On the whole, mutual harmony and benefits for all are emphasized in conversations about rose oil production. Firms, the Cooperative and growers share concerns about improving quality and sustainability and also keeping prices stable. Yet knowledge about international firms and the world market for cosmetic products is often presented as hardly attainable. The rose grower cited above who notes that attaining more knowledge about production would raise growers' bargaining power is a case in point. Why they do not indeed engage in organizing their own cooperative and production unit was explained by this farmer in terms of a lack of time and knowledge. The moral dimension of the price for her was not an urgent issue, as long as the prices were 'good', and the household could maintain its livelihood and a good rural life. Whether this diversified mode of livelihood with rose cultivation as an additional source of income would be reproducible for the next generations remains an open question.

\footnotetext{
${ }^{24}$ This 'feeling for the market' resonates the ambiguities involved in perfume markets, as discussed by Moeran (2005). He points out to the paradox between the contextually specific character of olfactory cultures and that nevertheless the global perfume marketing strategies claim ‘a universal semiotic communication’. 


\section{ACKNOWLEDGEMENTS}

Earlier versions of this chapter have been presented at the Max Planck Institute for Social Anthropology, the Universities of Pardubice and of Warsaw and also at the Conference of the European Association of Social Anthropologists (EASA) in July 2016, at a panel organized by Peter Luetchford and Giovanni Orlando. A subsequent version has been published within the Working Paper Series of the Max Planck Institute for Social Anthropology (no. 178, 2016). The author would like to thank Peter Luetchford and Giovanni Orlando for their thorough editorial assistance and suggestions, also colleagues at the Max Planck Institute in Halle, in Pardubice and Warsaw for their comments and discussion. Further thanks go to Chris Hann, James Carrier, Bruce Grant, Alessandro Testa, Deema Kaneff and two anonymous reviewers for useful suggestions, critique and improvements on the paper. Sincere thanks are due to the rose growers and rose oil processors and Gülbirlik as well as colleagues at the Süleyman Demirel University in Isparta, who have supported the research wholeheartedly. As usual the author is responsible for any shortcomings.

This paper draws on research that has received funding from the European Research Council under the European Union's Seventh Framework Programme (FP7/2007-2013)/ERC Grant agreement no. 340854 (REALEURASIA). 


\section{REFERENCES}

Altıntaş, A. (2009). Rose, rose water: Historical, therapeutic and cultural perspectives. Istanbul: Maestro.

Baydar, H. \& Kazaz, S. (2013). Yağ Gülü ve Isparta Gülcülü̆ğü. Isparta: Gülbirlik.

Beckert, J. (2011). Where do prices come from? Sociological approaches to price formation. Max Planck Institute for the Study of Societies Discussion Paper 11/3. Cologne: Max Planck Institute for the Study of Societies.

Besky, S. (2014). The Darjeeling distinction: Labour and justice on fair-trade tea plantations in India. Berkeley, Los Angeles, London: University of California Press.

Bourdieu, P. (2005). Principles of an economic anthropology. In: N. J. Smelser \& R. Swedberg (Eds.). The handbook of economic sociology. Princeton: Princeton University Press, pp. 75-89.

Carrier, J. G. (2018). Moral economy: What's in a name. Anthropological Theory, 18(1), 18-35.

Dulupçu, M. A. \& Gövdere, B. (2012). Bölgesel Gelişme Stratejileri için bir Perspektif: Yerel Bilgi A ğbağları Yaklaşımı. Türkiye Ekonomi Kurumu Tartışma Metni 2012/57: 135-165. Retrieved from: http ://www.tek.org.tr. Accessed on 25 September 2015.

Elyachar, J. (2005). Markets of dispossession: NGOs, economic development and the state in Cairo. Durham and London: Duke University Press.

Elyachar, J. (2012). Before (and after) neoliberalism: Tacit knowledge, secrets of the trade, and the public sector in Egypt. Cultural Anthropology, 27(1), 76-96.

Erçetin, N. A. (2014). Bir Zamanlar Isparta. İzmir: Erçetin Gülyağı San. Tic. A.Ş.

Goody, J. (1993). The culture of flowers. Cambridge University Press.

Gudeman, S. \& Rivera, A. (1990). Conversations in Columbia: The domestic economy in life and text. Cambridge, a.o.p.: Cambridge University Press.

Guyer, J. (2009). Composites, fictions, and risk: Toward an ethnography of price. In: C. Hann \& K. Hart (Eds.). Market and society: The Great Transformation today. Cambridge: Cambridge University Press, pp. 203-220.

Gülbirlik: Gül Üreticisinin Ortak Sesi 2007, Ocak-Şubat Mart sayıs1, Yı1 3, No 4, Isparta.

Gülbirlik. (2011). Brifing. (Unpublished activities report on and by Gülbirlik), Isparta.

Hann, C. (2010). Moral economy. In: K. Hart, J.-L. Laville \& A. D. Cattani (Eds.) The human economy: A citizen's guide, Cambridge, Malden: Polity, pp. 187-198.

Hann, C. (2018.) Moral(ity and) economy: Work, workfare, and fairness in provincial Hungary. EuropeanJournal of Sociology, 59(2), 225-254.

Karakuş, H. (2009). Silam Isparta. İstanbul: Heyamola Yayınları. 
Krul, M. (2016). Institutions and the challenge of Karl Polanyi: Economic anthropology after the neoinstitutionalist turn. Max Planck Institute for Social Anthropology Working Paper No. 168. Halle/Saale: Max Planck Institute for Social Anthropology.

Luetchford, P. (2008). Fair trade and a global commodity: Coffee in Costa Rica. London: Pluto Press.

Luetchford, P. (2012). Economic anthropology and ethics. In: J. G. Carrier (Ed.). A handbook of economic anthropology, $2^{\text {nd }}$ ed. Cheltenham, UK, Northampton, MA, USA: Edward Elgar, pp. 397-412.

Marx, K. (1986 [1887]). Capital: A critique of political economy. (Vol. I), Moscow: Progress publishers.

Moeran, B. (2005). Japanese fragrance descriptives and gender constructions: Preliminary steps towards an anthropology of olfaction. Etnofoor, 18(1), 97-123.

Moeran, B. (2009). Making scents of smell: Manufacturing and consuming incense in Japan. Human Organization, 68(4), 439-450.

Moeran, B. (2010). Snapshot: The Bulgarian Rose Oil Industry. In: Encyclopedia of world dress and fashion, vol. 9, "East Europe, Russia, and the Caucasus" (Ed.) D. Bartlett, Oxford University Press, pp. 424-425.

Palomera, J. \& Vetta, T. (2016). Moral economy: Rethinking a radical concept. Anthropological Theory, 16(4) 413-432.

Polanyi, K. (1977). The livelihood of man. New York: Academic Press.

Sallan Gül, S., C. Yılmaz, C. Ergun and A. Alican. (2010). İkon Olarak Gül: Kentsel kimliğin üretilmesinin sembolik anlamları. In: B. Kemikli and S. Turan (Eds.). Gül Kitabı: Gül kültürü üzerine incelemeler. Isparta: Isparta Belediyesi Yayınları, pp. 211-221.

Scott, J. (1976). The moral economy of the peasant: Rebellion and subsistence in Southeast Asia. New Haven: Yale University Press.

Temurçin, K. (2004). Isparta İlinde Sanayiinin Gelişimi ve Yapısı. Ankara Üniversitesi Türkiye Coğrafyası Araştırma ve Uygulama Merkezi Coğrafi Bilimler Dergisi, C.2, S.4. Ankara, pp. 87104.

Tool, M. R. (2002). Contributions to an institutionalist price determination. In: G. M. Hodgson (Ed.). A modern reader in institutional and evolutionary economics: Key concepts. Cheltenham, UK, Northampton, MA, USA: Edward Edgar, pp. 3-26.

Veblen, T. B. (1994 [1904]). The theory of business enterprise. London: Routledge/Thoemmes Press.

Yürekli Yüksel, N. (2010). Gülyağı ve Gül Konkreti. Tarımsal Ekonomi Araştırma Enstitüsü Bakış. Eylül 2010, pp-1-4.

Ziegler, C. (2007). Favored flowers: Culture and economy in a global system. Durham and London: Duke University Press. 